\title{
PENGARUH KUALITAS PELAYANAN DAN KUALITAS PRODUK KREDIT UKM TERHADAP LOYALITAS NASABAH PT BPR KERTA RAHARJA BANDUNG
}

\author{
Indra Prabhata \\ Institut Ilmu Sosial dan Manajemen STIAMI \\ indraprabhata@gmail.com
}

\begin{abstract}
Abstrak. Penelitian ini dilakukan untuk menganalisa seberapa besar pengaruh Kualitas Pelayanan terhadap Loyalitas Nasabah PT BPR Kerta Raharja Bandung, menganalisa seberapa besar pengaruh Kualitas Produk terhadap Loyalitas Nasabah PT BPR Kerta Raharja Bandung, dan menganalisa seberapa besar pengaruh Kualitas Pelayanan dan Kualitas Produk secara simultan terhadap Loyalitas Nasabah PT BPR Kerta Raharja Bandung.

Penelitian ini menggunakan metode korelasi untuk melihat seberapa besar pengaruh variabel bebas dan variabel terikat. Populasi penelitian ini adalah nasabah kredit UKM PT BPR Kerta Raharja Bandung yang berjumlah 576 orang dan yang dijadikan sampel dalam penelitian ini sebanyak 85 orang. Setiap responden diberikan sebanyak 30 pertanyaan dengan menggunakan skala Likert.

Berdasarkan hasil olah data menunjukkan bahwa pengaruh Kualitas Pelayanan terhadap Loyalitas Nasabah PT BPR Kerta Raharja Bandung adalah kuat, artinya bahwa hubungan kedua variabel tersebut adalah signifikan pada derajat kepercayaan kuat. Pengaruh Kualitas Produk terhadap Loyalitas Nasabah PT BPR Kerta Raharja Bandung adalah kuat, artinya bahwa hubungan kedua variabel tersebut adalah signifikan pada derajat kepercayaan kuat. Sedangkan pengaruh Kualitas Pelayanan dan Kualitas Produk secara simultan terhadap Loyalitas Nasabah PT BPR Kerta Raharja Bandung adalah kuat. Hal ini menunjukkan bahwa semakin baik kualitas pelayanan dan kualitas produk maka akan semakin meningkatkan loyalitas nasabah.
\end{abstract}

Kata Kunci: Kualitas Pelayanan, Kualitas Produk, Loyalitas Nasabah

Abstract. This research investigated how big the effect service quality on the customer loyality of the PT BPR Kerta Raharja Bandung, investigated how big the effect of product quality on the customer loyality of the PT BPR Kerta Raharja Bandung, investigated how big the effect of service quality and product quality by simultaneous on the customer loyality of PT BPR Kerta Raharja Bandung.

This research was used corelation methode to investigated how big the effect of dependent and independent variables. The research population is 576 customers of PT BPR Kerta Raharja and 85 peoples to be sampling in this research. Each respondents was given 30 questions by using likert scale.

Based on the data processing, indicated the effect of service quality on customer loyality of the PT $B P R$ Kerta Raharja is very adequate means that the relation between those variables significant on the degree of strong level. the effect of product quality on customer loyality of the PT BPR Kerta Raharja is very adequate means that the relation between those variables significant on the degree of strong level. The last, the effect of service quality and product quality on customer loyality of the PT BPR Kerta Raharja is very adequate means that the better of service quality and product quality, to further improve customer loyality.

Keywords: Service Quality, Product Quality, Customer Loyality.

\section{PENDAHULUAN}

Efisiensi pelayanan publik menjadi tema penting akhir-akhir ini karena ekonomi yang berat dihadapi oleh pemerintah, seperti merosotnya harga komoditi, resesi ekonomi, beban hutang luar negeri yang tinggi, dan lain-lain. Inefesiensi memang masih melekat sebagai titik lemah dari pelayanan publik. Darwin (Arfani, 1996: 217) mengemukakan bahwa inefisiensi pelayanan publik 
disebabkan oleh tingginya tingkat birokrasi, berkembangnya red-tape dalam pelayanan publik, rendahnya kualitas sumber daya manusia, produktifitas dan disiplin kerja yang rendah, meluasnya berbagai macam praktek maladministrasi di kalangan birokrat dan meningkatnya sisa anggaran pembangunan dari waktu ke waktu.

Upaya untuk mencari alternatif perbaikan pelayanan publik terus menerus diusahakan, upaya itu setua umur konsep pelayanan publik itu sendiri. Sampai sekarangpun upaya tersebut masih berlanjut dan bandul pendulumnya bergerak dari satu titik domain yang klasik ke domain yang kontemporer. Kualitas pelayanan publik harus dimulai dengan melakukan revitalisasi birokrasi kita dengan melakukan revitalisasi kelembagaan. Kelembagaan yang kurang merangsang produktivitas aparatur publik harus bisa diatasi dengan melakukan perampingan struktur dan peningkatan kualitas aparatur publik.

Berkaitan dengan revitalisasi kelembagaan untuk perbaikan kualitas pelayanan publik, maka pada akhir tahun 90an, muncul konsep baru yang disebut New Public Management. Inti konsep ini adalah mentransformasikan kinerja yang selama ini dipergunakan oleh sektor swasta dan bisnis ke sektor publik (Thoha, 2014: 71). Konsep ini menganjurkan agar mengatur dan mengendalikan pelayanan publik tidak jauh berbeda mengatur dan mengendalikan bisnis. Konsep inilah yang kemudian dikenal dengan upaya mewiraswastakan birokrasi pemerintahan sebagai upaya meningkatkan kualitas pelayanan publik. Upaya ini mempunyai sepuluh prinsip-prinsip pelaksanaan yaitu pemerintahan harus bersifat sebagai katalis, pemerintahan milik masyarakat, pemerintah kompetitif, pemerintah berorientasi misi, pemerintah berorientasi pada hasil, pemerintah berorientasi pelanggan, pemerintah swasta, pemerintah antisipatif, pemerintah desentralisasi dan pemerintah berorientasi pasar (Thoha, 2014: 78).

Dalam konsep New Public Management, pemberian pelayanan publik kepada masyarakat tidak harus dilakukan oleh pemerintah, akan tetapi pemerintah dapat bekerjasama dan mengembangkan kemitraan, baik dengan kelompok swasta maupun perorangan. Menurut Undang-Undang No. 25 Tahun 2009, penyelenggara pelayanan publik adalah setiap institusi penyelenggara negara, korporasi, lembaga independen yang dibentuk berdasarkan undang-undang untuk kegiatan pelayanan publik, dan badan hukum lain yang dibentuk semata-mata untuk kegiatan pelayanan publik.

Pemerintah Kabupaten Bandung merupakan salah satu kabupaten yang mendirikan BUMD. Salah satu BUMD yang didirikan adalah PT Bank Perkreditan Rakyat Kerta Raharja. Pada awal pendiriannya didasari SK Gubernur Daerah Tingkat. I Jawa Barat, maka sejak 16 Juli 1967 resmi berdiri BKPD Kecamatan Soreang dengan modal pendirian sebesar Rp. 836.848,- yang didapat dari setoran IPEDA se-Kecamatan Soreang. Setoran modal dilanjutkanoleh Pemerintah Daerah Tingkat II Kabupaten Bandung hingga sampai dengan tanggal 11 April 1996 terkumpul sebesar Rp. 69.075.000,-. Sejalan dengan perkembangan dari tahun ke tahun dan adanya perubahan nama menjadi Perusahaan Daerah Bank Perkreditan Rakyat Kabupaten Bandung (PD BPR Kab. Bandung) modal harus segera ditambah, maka pemerintah daerah Kabupaten Bandung selaku pemilik melakukan penyuntikan modal dan dari penyisihan laba setiap tahun disisihkan sebagai modal. Maka modal disetor PD BPR Kab. Bandung sampai dengan tanggal 31 Desember 2007 sebesar Rp. 1.013.526.233,90 dengan total asset sebesar Rp. 21.391.309.503,21. Berdasarkan Peraturan Daerah (PERDA) Nomor 23 Tahun 1996 bahwa PD BPR Kab. Bandung dalam melakukan usahanya berazaskan demokrasi ekonomi dengan prinsip kehati-hatian. Tujuan didirikannya PD BPR Kab. Bandung dalam PERDA Nomor 23 Tahun 1996 adalah untuk membantu dan mendorong pertumbuhan perekonomian dan pembangunan daerah di segala bidang serta sebagai salah satu sumber pendapatan asli daerah dalam rangka meningkatkan taraf hidup rakyat. 
Indra Prabhata, Pengaruh Kualitas Pelayanan Dan Kualitas Produk Kredit Ukm ...

Seiring dengan perkembangan dunia perbankan di Indonesia dan untuk mewujudkan profesionalitas dan daya saing perusahaan dalam pengelolaan pelayanan publik dalam bidang finansial, PD BPR Kab. Bandung pada tanggal 27 Maret 2015 berubah nama dan bentuk badan hukum menjadi PT Bank Perkreditan Rakyat Kerta Raharja (PT BPR Kerta Raharja) sesuai dengan Surat Keputusan Otoritas Jasa Keuangan Nomor KEP-11/KR.2/2015 tentang Pengalihan Izin Usaha atas perubahan badan hukum dari PD Bank Perkreditan Rakyat Kabupaten Bandung kepada PT Bank Perkreditan Rakyat Kerta Rahaja dan Surat Keputusan Otoritas Jasa Keuangan Nomor KEP-12/KR.2/2015 tentang Penetapan Penggunaan Izin Usaha atas nama PD Bank Perkreditan Rakyat Kabupaten Bandung menjadi izin usaha atas nama PT Bank Perkreditan Rakyat Kerta Rahaja.

Perubahan diatas yang efektif berlaku pada tanggal 7 April 2015, seharusnya juga diimbangi dengan semakin baiknya proses pelayanan publik pada PT BPR Kerta Raharja. Namun berdasarkan pengamatan awal pada lokasi penelitian, belum banyak perubahan mendasar yang dilakukan pasca perubahan menjadi perusahaan perseroan. Hal mendasar yang dihadapi oleh PT BPR Kerta Raharja adalah rendahnya loyalitas nasabah. Ada dua kategori fenomena yang dapat terlihat dari pengamatan penulis terhadap PT BPR Kerta Raharja tentang loyalitas nasabah yaitu fenomena kreditur dan fenomena debitur.

Fenomena kreditur yaitu fenomena nasabah yang berkaitan dengan permasalahan nasabah untuk produk simpanan (tabungan, giro, dan deposito) yaitu terjadinya penurunan saldo tabungan secara mencolok, saldo giro rata-rata menurun, rendahnya tingkat transaksi perbankan, menurunnya jumlah nasabah, dan sering adanya cek kosong yang dicarikan. Fenomena debitur yaitu fenomena nasabah yang berkaitan dengan permasalahan nasabah untuk produk kredit yaitu saldo rekening sering mengalami overdraft, pembayaran angsuran kredit maupun bunga yang tersendat, sering mengajukan penundaan pembayaran, mengajukan perpanjangan kredit, melarikan diri atau kabur dari penyelesaiian kredit, terjadi penyimpangan penggunaan kredit, dan hubungan dengan bank semakin renggang.

Fenomena diatas diduga dipengaruhi oleh kualitas pelayanan dan kualitas produk perbankan yang ditawarkan oleh PT BPR Kerta Raharja. Kualitas pelayanan merupakan salah satu faktor kunci bagi keberhasilan bank sebagai perusahaan jasa dan tidak dapat dipungkiri dalam dunia bisnis saat ini, karena tidak ada yang lebih penting lagi bagi sebuah bank kecuali menempatkan masalah kepuasan dan loyalitas terhadap nasabah melalui pelayanan sebagai salah satu komitmen bisnisnya. Jika pelayanan yang diberikan kepada nasabah itu baik dan memuaskan maka akan berpengaruh pada peningkatan loyalitas nasabah (Rusdarti, 2004: 54-65).

Kualitas pelayanan menjadi penting karena dalam industri jasa perbankan, kepuasan nasabah sangat bergantung pada kualitas layanan yang diberikan. Apabila kita kaji lebih dalam, kepuasan nasabah tersebut berdampak lebih jauh lagi pada loyalitas nasabah. Loyalitas nasabah tersebut dapat dikatakan wujud nyata dari keberhasilan suatu perusahaan jasa dalam menjalankan segala kegiatan usahanya.

Hal lain yang diduga mempengaruhi loyalitas nasabah pada PT BPR Kerta Raharja adalah kualitas produk yang ditawarkan. Kualitas produk perbankan semakin harus variatif sesuai dengan tuntutan dan kebutuhan masyarakat. Sementara PT BPR Kerta Raharja hanya memberikan produk yang bersifat klasik dan standar. Memang harus dapat juga dipahami dengan bahwa BPR terkadang terbelenggu oleh kekurangan dana, mengingat bank adalah bisnis kepercayaan maka yang akan memperoleh kepercayaaan lebih besar adalah bank-bank umum sawasta maupun pemerintah yang memiliki kapital besar. Hal ini membuat BPR tidak mempunyai anggaran untuk melakukan promosi ataupun memberikan rangsangan berupa balas jasa yang akan diberikan kepada para nasabah, baik dalam bentuk bunga yang kompetitif, souvenir, ataupun kompensasi lainnya. Dalam hal produk kredit juga belum 
begitu diminati, walaupun prosesnya lebih mudah dari bank-bank umum namun bunganya masih terlalu tinggi dibandingkan dengan bank-bank umum tersebut. Hal ini menyebabkan nasabah hanya bisa mengajukan kredit tanpa memiliki kemampuan untuk melakukan pembayaran angsuran setelah jatuh tempo.

Kaitan kualitas pelayanan dan loyalitas nasabah dikemukan oleh Zeithaml dan Bitner (Lupiyoadi, 2014: 288) bahwa faktor utama penentu loyalitas adalah persepsi pelanggan terhadap kualitas jasa (pelayanan). Lebih lanjut Tjiptono (Sangadji dan Sopiah, 2013: 100) menjelaskan bahwa apabila jasa (pelayanan) yang diterima atau disarankan sesuai dengan yang diharapkan, kualitas jasa dipersepsikan baik dan memuaskan. Dengan demikian loyalitas pada dasarnya adalah fungsi dari harapan dan persepsi terhadap layanan yang didapatkan atau digunakan oleh pelanggan (McKenchie dalam Sangadji dan Sopiah: 2013, 115).

Jadi, kualitas pelayanan merupakan salah satu faktor yang fundamental dan merupakan suatu proses penting dalam pembentukan loyalitas. Jika kualitas pelayanan yang dirasakan oleh nasabah baik maka akan meningkatkan loyalitas. Begitu juga sebaliknya, jika kualitas pelayanan yang dirakan nasabah buruk maka akan mengurangi atau bahkan meniadakan loyalitas tersebut.

Selain kualitas pelayanan, ada hal lain yang membentuk loyalitas nasabah yaitu kualitas produk. Produk memiliki arti penting bagi perusahaan karena tanpa adanya produk, perusahaan tidak akan dapat melakukan apapun dari usahanya. Konsumen akan membeli produk kalau merasa cocok, karena itu produk harus disesuaikan dengan keinginan ataupun kebutuhan pembeli agar pemasaran produk berhasil. Dengan kata lain, pembuatan produk lebih baik diorientasikan pada keinginan pasar atau selera konsumen. Menurut Adam \& Ebert (1992: 256), menyatakan bahwa "quality is the customer's perception". Artinya bahwa pelanggan menilai baik buruknya kualitas suatu produk itu berdasarkan persepsinya. Suatu produk dikatakan berkualitas jika memenuhi kebutuhan dan keinginan pembeli.

Sedangkan menurut Selnes (1993:21) mendefinisikan "kualitas produk adalah segala sesuatu yang memiliki nilai di pasar sasaran (target market) dimana kemampuannya memberikan manfaat dan kepuasan, termasuk hal ini adalah benda, jasa, organisasi, tempat, orang, dan ide".

Menurut Kotler dan Amstrong (2001: 346), "kualitas produk adalah segala sesuatu yang dapat ditawarkan ke pasar untuk mendapatkan perhatian, dibeli, digunakan, atau dikonsumsi yang dapat memuaskan keinginan atau kebutuhan".

Dari definisi produk diatas, maka kualitas produk adalah keseluruhan ciri serta dari suatu produk atau pelayanan pada kemampuan untuk memuaskan kebutuhan yang dinyatakan/ tersirat (Kotler, 2005: 49).

Menurut Payne (Hidayat, 2009: 59) mendefinisikan "kualitas produk adalah suatu bentuk dengan nilai kepuasan yang kompleks". Nilai yang diberikan nasabah berhubungan dengan benefit atau keuntungan yang akan diterimanya. Kualitas produk perbankandidapatkan dengan cara menemukan keseluruhan harapan nasabah, meningkatkan nilai produk atau pelayanan dalam rangka memenuhi harapan nasabah tersebut.

Kualitas layanan dan kualitas produk berpengaruh signifikan terhadap loyalitas nasabah. Kualitas produk berpengaruh secara signifikan terhadap kepuasan nasabah dan kepuasan nasabah perpengaruh signifikan terhadap loyalitas nasabah. Artinya adalah kualitas pelayanan dan kualitas produk terbukti secara bersama-sama mempunyai pengaruh yang signifikan terhadap loyalitas nasabah baik secara langsung maupun tidak langsung.

$$
\text { Lupiyoadi }
$$

(2001: mengemukakan bahwa dalam meningkatkan loyalitas konsumen ada lima faktor yang perlu diperhatikan yaitu kualitas produk, kualitas pelayanan, harga, kepuasan dan kemudahan mendapatkan produk. Konsumen akan merasa puas jika biaya dan produk yang diperoleh 
Indra Prabhata, Pengaruh Kualitas Pelayanan Dan Kualitas Produk Kredit Ukm ...

relatif mudah, nyaman dan efisien dalam mendapatkan produk dan pelayanan.

Dari beberapa penjelasan diatas, maka penulis gambarkan sebagai berikut pada gambar 1 .

Berdasarkan kerangka konseptual penelitian seperti yang telah dikemukakan pada gambar 1, maka dapat dirumuskan hipotesis penelitian sebagai berikut:
1. Kualitas pelayanan berpengaruh signifikan terhadap loyalitas nasabah;

2. Kualitas produk berpengaruh signifikan terhadap loyalitas nasabah;

3. Kualitas pelayanan dan kualitas produk berpengaruh signifikan terhadap loyalitas nasabah.

Gambar 1. Kerangka Konseptual Penelitian

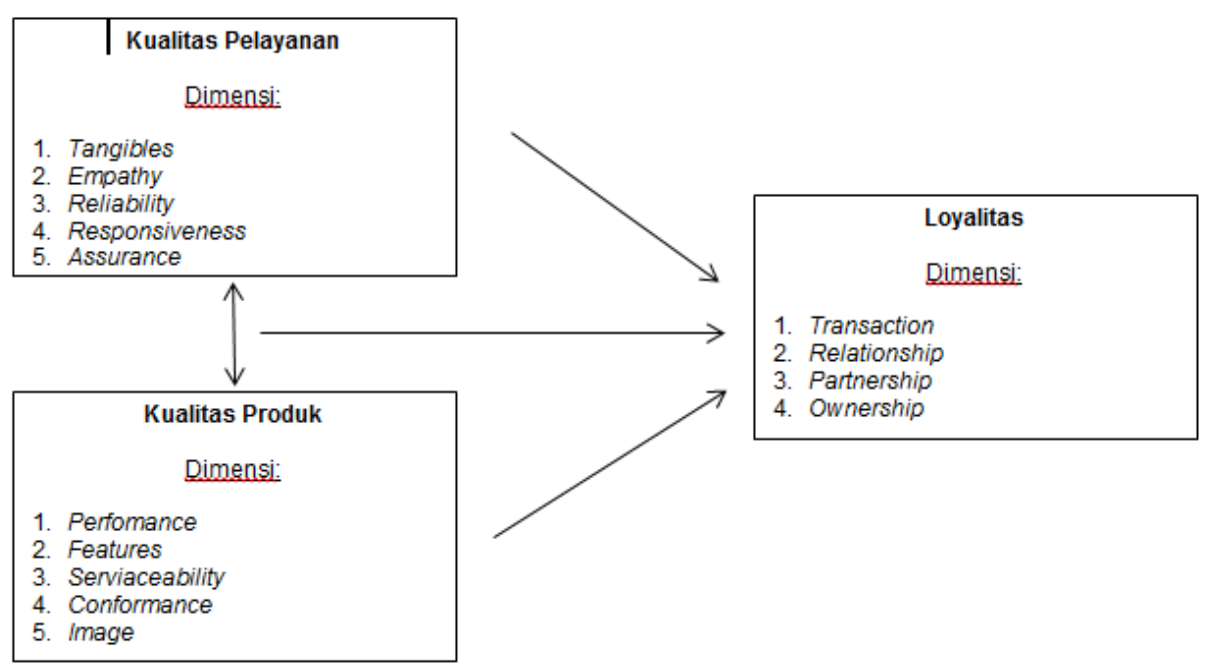

\section{METODE PENELITIAN}

Penelitian yang digunakan dalam penelitian ini adalah pendekatan kuantitatif, yaitu penelitian yang menekankan analisisnya pada data numerical atau angka yang diperoleh dengan metode statistik serta dilakukan pada penelitian inferensial atau dalam ranka pengujian hipotesis sehingga diperoleh signifikansi hubungan antara variabel yang diteliti.

Penelitian ini termasuk dalam hypothetico-deductive method, artinya penelitian dalam tesis ini adalah suatu proses yang dimulai dengan observasi berupa pengamatan pendahuluan terhadap fenomenafenomena administrasi publik dalam bentuk penghimpunan data awal.

Langkah berikutnya yaitu dilakukan penelitian survei untuk mengambil suatu generalisasi dari pengamatan terhadap variabel kualitas pelayanan dan kualitas produk sebagai faktor yang mempengaruhi loyalitas nasabah di PT Bank Perkreditan
Rakyat Kerta Raharja. Penelitian ini merupakan bagian dari penelitian administrasi publik dalam new public administration yang bertujuan untuk meningkatkan keterjangkauan pemerintah terhadap pelayanan publik.

Populasi dalam penelitian ini adalah 576 orang debitur yang tercatat mengajukan kredit UKM di Kantor Pusat PT Bank Perkreditan Rakyat Kerta Raharja per hasil audit 31 Desember 2014.

Sampel adalah bagian bagian dari jumlah dan karakteristik yang dimiliki oleh populasi tersebut (Sugiyono, 2013 : 116). Sampel adalah sebagian dari populasi yang karakteristiknya hendak diteliti (Djarwanto, 1994: 43). Agar mendapatkan sampel yang representatif dari populasi, maka subjek dalam populasi peluang yang sama untuk menjadi sampel. Dengan jumlah populasi sebanyak 576 orang debitur dengan taraf presentase kelonggaran penelitian sebesar 10\% dengan perhitungan: 


$$
n=\frac{N}{1+N e^{2}}=\frac{576}{6,76}=85,2=85
$$

Sehingga didapat 85,2 dibulatkan menjadi 85 responden.

\section{HASIL DAN PEMBAHASAN}

Kualitas pelayanan berpengaruh positif terhadap loyalitas nasabah berdasarkan output komputer program SPSS For Windows Version 17 yang didapat koefisien korelasi parsial variabel kualitas pelayanan (X1) nilai sebesar 0,821 sehingga dapat disimpulkan bahwa hasil analisis antara variabel kualitas pelayanan (X1) terhadap variabel loyalitas nasabah (Y) bersifat positif, jadi tingkat hubungannya sangat kuat.

Karena nilai tersebut belum menunjukkan besaran hubungan, maka besarnya pengaruh tersebut dihitung secara manual dengan menggunakan rumus koefisien determinasi sebagai berikut : $\mathrm{Kd}=$ $\mathrm{r} 2 \times 100 \%$. Dimana $\mathrm{r}$ adalah nilai analisis koefisien korelasi sebesar 0,821. Hasil perhitungan selanjutnya sebagai berikut:

$$
\begin{aligned}
\mathrm{Kd}=\mathrm{r} 2 & \times 100 \% \\
= & 0,8212 \times 100 \% \\
& =67,4 \%
\end{aligned}
$$

Dengan hasil tersebut di atas dapat dikatakan bahwa variabel kualitas pelayanan (X1) mempunyai pengaruh $67,4 \%$ terhadap loyalitas nasabah dan sisanya $32,6 \%$ disebabkan oleh faktor-faktor yang lainnya atau dapat dikatakan bahwa variabel kualitas pelayanan (X1) memiliki tingkat pengaruh sebesar $67,4 \%$ terhadap loyalitas nasabah di PT BPR Kerta Raharja.

Dari output komputer program SPSS For Windows Version 17 yang didapat koefisien korelasi parsial variabel loyalitas pelayanan (X1), didapatkan kualitas pelayanan $(\mathrm{X} 1), \mathrm{p}=0,000(\mathrm{p}<0,05)$ artinya secara parsial berpengaruh terhadap Y. Hal ini menunjukkan pada Uji $\mathrm{T}$ bahwa faktor kualitas pelayanan secara parsial berpengaruh terhadap loyalitas nasabah, karena $\mathrm{t}_{\text {tabel }}<\mathrm{t}_{\text {hitung }}$ yaitu $0,00<0,05$. Hal ini menunjukkan faktor kualitas pelayanan berpengaruh kuat dalam kaitannya dengan loyalitas nasabah di PT BPR Kerta Raharja.

Kualitas pelayanan berpengaruh signifikan terhadap loyalitas nasabah. Hal ini berarti bahwa semakin baiknya kualitas pelayanan yang diberikan oleh Bank BPR Kerta Raharja membuat nasabah menjadi loyal. Kondisi ini, mungkin saja disebabkan karena nasabah perbankan sudah sangat kritis terhadap masalah-masalah layanan perbankan. Sehingga untuk memutuskan loyal pada sebuah bank, nasabah harus berada pada posisi puas lebih dahulu terhadap pelayanan yang diberikan. Di samping itu sifat dari layanan perbankan yang intangibles dimana seorang nasabah memutuskan loyal memerlukan waktu yang cukup untuk menikmati atau mengkonsumsi kualitas pelayanan yang menurut bank sudah ditingkatkan kualitasnya. Jika seorang nasabah sudah menikmati dan puas maka nasabah akan loyal pada bank tersebut.

Kualitas produk juga berpengaruh positif terhadap loyalitas nasabah berdasarkan output komputer program SPSS For Windows Version 17 yang didapat koefisien korelasi parsial variabel kualitas produk (X2) sebesar 0,848 sehingga dapat disimpulkan bahwa hasil analisis antara variabel kualitas produk (X2) terhadap variabel loyalitas nasabah (Y) bersifat positif, jadi tingkat hubungannya sangat kuat.

Nilai tersebut belum menunjukkan besaran hubungan, maka besarnya pengaruh dihitung secara manual dengan menggunakan rumus koefisien determinasi. Hasil perhitungan selanjutnya sebagai berikut :

$$
\begin{aligned}
\mathrm{Kd}=\mathrm{r} 2 & \times 100 \% \\
& =0,8482 \times 100 \% \\
& =71,9 \%
\end{aligned}
$$

Dengan hasil tersebut di atas dapat dikatakan bahwa variabel kualitas produk 
Indra Prabhata, Pengaruh Kualitas Pelayanan Dan Kualitas Produk Kredit Ukm ...

(X2) mempunyai pengaruh $71,9 \%$ terhadap loyalitas nasabah dan sisanya $28,1 \%$ disebabkan oleh faktor-faktor yang lainnya atau dapat dikatakan bahwa variabel kualitas produk (X2) memiliki tingkat pengaruh sebesar $71,9 \%$ terhadap loyalitas nasabah di PT BPR Kerta Raharja.

Dari output komputer program SPSS For Windows Version 17 yang didapat koefisien korelasi parsial variabel loyalitas produk (X2), kualitas produk (X2), $\mathrm{p}=0,000$ $(\mathrm{p}<0,05)$ artinya secara parsial berpengaruh terhadap Y. Hal ini menunjukkan pada Uji T bahwa faktor kualitas produk secara parsial berpengaruh terhadap loyalitas nasabah, karena $t_{\text {tabel }}<t_{\text {hitung yaitu }} 0,00<0,05$. Hal ini menunjukkan faktor kualitas produk berpengaruh kuat dalam kaitannya dengan loyalitas nasabah di PT BPR Kerta Raharja.

$$
\text { Kualitas produk berpengaruh }
$$
signifikan terhadap loyalitas nasabah. Hal ini berarti bahwa semakin baiknya kualitas produk yang diberikan oleh Bank BPR Kerta Raharja membuat nasabah menjadi loyal kepada Bank.Seperti kualitas pelayanan, hubungan positif dan signifikan antara kualitas produk dan loyalitas nasabah, mungkin saja disebabkan karena proses dan prosedur kredit yang diluncurkan relatif lebih mudah dengan tetap memperhatikan manajemen resiko pada bank. Masyarakat atau nasabah bank hanya akan berurusan dengan bank berdasarkan kepada tingkat kebutuhannya semata sehingga proses mencari bank dengan kualitas produk terbaik masih terus dilakukan. Bank adalah lembaga pengelola dana yang bekerja atas dasar kepercayaan masyarakat, terutama para nasabahnya.pada bank tersebut.

Hubungan antara variabel kualitas pelayanan (X1) dan variabel kualitas produk (X2) terhadap variabel loyalitas nasabah (Y) sebesar 0,878 sehingga dapat disimpulkan bahwa hasil analisis antara variabel kualitas pelayanan (X1) dan variabel kualitas produk (X2) terhadap variabel loyalitas nasabah (Y) bersifat positif, jadi tingkat hubungannya sangat kuat.
Pada nilai koefisien determinasi didapatkan nilai $\mathrm{R}$ Square $=0,770=77 \%$, artinya bahwa variabel independen yg diteliti memiliki pengaruh kontribusi sebesar $77 \%$ terhadap variabel $\mathrm{Y}$, sedangkan $23 \%$ lainnya dipengaruhi oleh faktor-faktor lain diluar variabel yg diteliti.

Untuk Nilai Uji F, didapatkan nilai sig $=0,000(\mathrm{p}<0,05)$ artinya semua variable independen secara simultan memiliki pengaruh yang signifikan terhadap variabel Y.

\section{SIMPULAN DAN SARAN}

Berdasarkan dari hasil analisis serta pembahasan mengenai pengaruh kualitas pelayanan dan kualitas produk terhadap loyalitas nasabah di PT. BPR Kerta Raharja, penulis dapat menyimpulkan:

1. Kualitas pelayanan berpegaruh signifikan terhadap loyalitas nasabah, variabel kualitas pelayanan mempunyai pengaruh kuat terhadap loyalitas nasabah di PT BPR Kerta Raharja.

2. Kualitas produk berpegaruh signifikan terhadap loyalitas nasabah, variabel kualitas produk mempunyai pengaruh kuat terhadap loyalitas nasabah di PT BPR Kerta Raharja.

3. Kualitas pelayanan dan kualitas produk secara bersama-sama berpengaruh signifikan terhadap loyalitas nasabah, kualitas pelayanan dan kualitas produk secara bersama-sama memiliki pengaruh kontribuksi kuat terhadap loyalitas nasabah.

Pada akhir penulisan jurnal ini, selanjutnya penulis mengemukakan beberapa saran yang dapat dijadikan bahan pertimbangan lebih lanjut sebagai berikut:

1. Untuk meningkatkan loyalitas nasabah dalam hal kualitas pelayanan, walaupun sudah dalam kondisi baik, PT. BPR Kerta Raharja perlu meningkat brosur dan materi informasi penunjang produk lainnya, proses pelayanan dalam memenuhi kebutuhan nasabah, pelayanan yang dapat membangkitkan kepercayaan nasabah.

2. Untuk meningkatkan loyalitas nasabah dalam hal kualitas produk, PT. BPR Kerta Raharja perlu mempertahankan dan 
memelihara kualitas produk yang sudah baik.

3. Untuk penelitian selanjutnya diharapkan penelitiannya dilakukan secara khusus pada cabang tertentu dan dengan jangka waktu yang lebih lama.

\section{DAFTAR PUSTAKA}

Adam, E E dan Ebert R J. 1992. Production and Operation Management; Concept, Models and Behavior 5th Edition. Prentice Hall.

Arfani, Riza Noer. 1996. Demokrasi Indonesia Kontemporer. Jakarta: PT Raja Grafindo Persada.

Arikunto, S. 2002. Prosedur Suatu Penelitian: Pendekatan Praktek Edisi Kelima. Jakarta: Rineka Cipta.

Azwar, S. 2000. Reliabiltas dan Validitas. Yogyakarta : Pustaka Pelajar.

Chorafas, Dimitris. 2000. Managing Credit Risk: Analysing, Rating and Pricing The Probability of Default. London: Euromoney Books.

Colquitt, Joetta. 2007. Credit Risk Management: How to Avoid Lending Disasters and Maximize Earnings. New York: McGraw-Hill.

Dharmayanti Diah. 2006. Analisa Sensitivitas Respon Konsumen Terhadap Eksistensi Merek (Brand Extension) Pada Maragrine Merek Filma di Surabaya. (Jurnal Manajemen Pemasaran Volume 1 Nomor 2). Surabaya.

Djarwanto, Ps. 1994. Petunjuk Teknis Penusunan Skripsi. Yogyakarta: BPFE UGM.

Feigenbaum, A.V. 2000. Kendali Mutu Terpadu Jilid 1. Edisi Ketiga. Jakarta: Erlangga.

Hidayat, Rahmat. 2009. Pengaruh Kualitas Layanan, Kualitas Produk dan Nilai Nasabah Terhadap Kepuasan dan Loyalitas Nasabah Bank Mandiri. (Jurnal Manajem dan Kewirausahaan Vol.11 No.1 Hlm. 59-72). Surabaya: Fakultas Ekonomi Universitas Kristen Petra.
Keban, Yeremias T. 2014. Enam Dimensi Strategis Administrasi Publik Edisi 3. Yogyakarta: Gava Media.

Kotler, Philip dan Gary Amstrong. 2001. Prinsip-Prinsip Pemasaran. Jakarta: Erlangga. dan Kevin Lane Keller. 2008. Manajemen Pemasaran Edisi 12 Jilid 2. Jakarta: Indeks.

2005. Manajemen Pemasaran Jilid

2 Edisi 11. Jakarta: Indeks.

---------. 2002. Manajemen Pemasaran Jilid 1. Jakarta: Prenhallindo.

Lupiyoadi, Rambat. 2014. Manajemen Pemasaran Jasa Edisi 3. Jakarta: Salemba Empat.

-. 2001. Manajemen Pemasaran Jasa (Teori dan Praktik). Jakarta: Salemba Empat.

McDowell, Banks. 2002. Ethics and Excuses: The Crisis in Professional Responsibility. London: Quorum Books.

Musanto, Trisno. 2004. Faktor-Faktor Kepuasan Pelanggan dan Loyalitas Pelanggan: Studi Kasus Pada CV. Sarana Media Advertising Surabaya. (Jurnal Manajemen \& Kewirausahaan. Vol. 6, No. 2, Hlm 123 - 136). Surabaya: Fakultas Ekonomi Universitas Kristen Petra.

Mustafa, Zainal. 2009. Mengurai Variabel Hingga Instrumentasi. Yogyakarta: Graha Ilmu.

Parasuraman, et. al. The Roles of Price, Performance, and Expectations in Determining Satisfaction in Service Exchanges. (Journal of Marketing. pp. 46-61).

Rusdarti, 2004, Pengaruh Kualitas Pelayanan dan Nilai Pelayanan terhadap Loyalitas Nasabah pada Bank BPD Jawa Tengah Cabang Semarang. (Jurnal Bisnis Strategi. Vol. 13, Juli 2004. Hlm. 54 - 65). Semarang.

Sangadji, Etta Mamang dan Sopiah. 2013. Perilaku Konsumen. Yogyakarta: Andi. 
Indra Prabhata, Pengaruh Kualitas Pelayanan Dan Kualitas Produk Kredit Ukm ...

Sekaran, Umar. 2000. Metode Penelitian untuk Bisnis. Edisi Keempat. Jakarta: Salemba Empat.

Selnes, Fred, 1993. An Examination of the Effect of Product Performance on Brand Reputation, Satisfaction and Loyalty (European Journal of Marketing. 27 (9), 19-35).

Schroeck, Gerhard. 2002. Risk Management and Value Creation in Financial Institutions. New Jersey: John Wiley \& Sons, Inc.

Sugiyono. 2008. Metode Penelitian Bisnis. Bandung: CV Alfabeta.

--------. 2013. Metode Penelitian Bisnis. Bandung: CV Alfabeta.

Thoha, Miftah. 2014. Ilmu Administrasi Publik Kontemporer. Jakarta: Kencana Prenadamedia Group.

Tjiptono, Fandy. 1997. Prinsip-Prinsip Total Quality Service. Yogyakarta: Andi.

Tunggal, Amin Widjaja. 2008. Dasar-Dasar Customer Relationship Management (CRM). Jakarta: Harvarindo.

Umar, Husein. 2010. Desain Penelitian Manajemen Strategik: Cara Mudah Meneliti Masalah-Masalah Manajemen Strategik Untuk Skripsi dan Praktik Bisnis. Jakarta: Pegawai Pers.

Zeithaml, Valarie A dan Mary Jo Bitner.1996. Service Marketing: Integrating Customer Focus Across The Firm. First Edition. USA: McGraw-Hill Companies Inc. 